ISSN 0258-7122

Bangladesh J. Agril. Res. 36(4): 711-722, December 2011

\title{
INTEGRATED NUTRIENT MANAGEMENT FOR POTATO- MUNGBEAN-T.AMAN RICE CROPPING PATTERN UNDER LEVEL BARIND AGROECOLOGICAL ZONE
}

\author{
M. R. A. MOLLAH ${ }^{1}$, NAJRUL ISLAM ${ }^{2}$ AND M. A. R. SARKAR ${ }^{3}$
}

\begin{abstract}
A field experiment was conducted at the Multiplication Testing Site (MLT), Joypurhat Sadar upazila with Potato- Mugnbean -T. Aman rice cropping pattern during November/2007 to November/2008 to verify different nutrient management approaches and to determine the economic dose of fertilizer for the said cropping pattern. The experiment was designed with five treatments for whole of the cropping pattern in a randomized complete block design with six replications. The treatments were, soil test based fertilizer dose for moderate yield goal, soil test based fertilizer dose for high yield goal, integrated plant nutrient management, farmers' practice, and control. Cowdung was applied at the first crop potato only in the cropping sequence. The varieties for potato, mungbean and T. Aman rice were Diamant, BARI Mung-6, and BR11, respectively. The results demonstrated that the tuber yield of potato, seed yield of mungbean, and grain yield of T. Aman rice were significantly influenced by the different treatments. The highest tuber yield (25.01 t/ha) was obtained from integrated plant nutrient management treatment. In mungbean, the highest seed yield (1384 kg/ha) was also recorded from NPKS for high yield goal with residual cowdung treatment. The results of NPKS application for high yield goal with residual cowdung had a positive effect on seed yield of mungbean. Grain and straw yields of T. Aaman rice were also significantly influenced by different treatments. The highest grain yield (5.68 t/ha) and straw yield (5.82 t/ha) were also observed in NPKS for high yield goal with residual cowdung treatment. The results also indicated that the residual cowdung had a positive effect on grain and straw yields of T. Aman rice. Cost and return analysis of different nutrient management packages for the whole cropping pattern showed that the highest marginal benefit cost ratio (8.64), gross return (Tk. 3,79,960/ha) and gross margin (Tk. 3,43,360/ha) were obtained from integrated plant nutrient management treatment and the lowest from soil test based fertilizers for moderate yield goal treatment. So, considering crop productivity, economic return, and soil fertility, integrated plant nutrient management for high yield goal with 5 t/ha cowdung could be recommended for the Potato-Mungbean-T Aman rice cropping pattern at Joypurhat and similar soils of Level Barind agroecological zone for sustainable higher yield.
\end{abstract}

Keywords: Integrated nutrient management, cropping pattern, level Barind agroecological zone.

${ }^{1}$ Agricultural Research Station, Bangladesh Agricultural Research Institute (BARI), Bogra, ${ }^{2 \& 3}$ Professor, Department of Agronomy, Bangladesh Agricultural University (BAU), Mymensingh, Bangladesh. 


\section{Introduction}

Soil fertility is a dynamic property, which varies with inherent status of soil, crops, cropping intensity, and input use. More than $50 \%$ of our cultivated soil contains organic matter below the critical level. Annual depletion of plant nutrients in the intensively cropped area ranges from 180 - to more than $250 \mathrm{~kg} / \mathrm{ha}$ (Mollah et al., 2008). High and medium highland comprising $60 \%$ of total cultivated land, which in most cases deficient in essential nutrients, such as nitrogen, phosphorus, potassium, and sulphur. The low organic matter content, higher cropping intensity, improper cropping sequence, and faulty management practices are the major causes of depletion of soil fertility. The productivity, particularly the yield per unit area of a wide range of crops in Bangladesh is in a state of stagnating condition due to (1) little or no addition of organic matter to the soil, (2) Intensive cropping throughout the year, (3) Nutrient depletion, (4) Imbalanced fertilization, and (5) poor management practices in crop production (Miah, 1994)

A crop production system with high yield targets cannot be sustainable unless balanced nutrient inputs are supplied to soil against nutrient removable crops (Bhuiyan et al., 1991). Sequential cropping ensures maximization of efficient use of moisture and nutrients from soil. Integrated nutrient management for prevailing cropping systems appears to be one of the effective ways to meet the economical nutrition requirement of crop.

Use of fertilizer is an essential component of modern farming with about $50 \%$ of the world crop production (Pradhan, 1992). The use of fertilizer nutrients in different countries of this region (Asia) has increased considerably with a maximum in the republic of Korea (509 kg/ha/yr) as against only $102 \mathrm{~kg} / \mathrm{ha} / \mathrm{yr}$ in Bangladesh (Karim et al., 1994). Nevertheless, it is true that sustainable production of crops cannot be maintained by using only chemical fertilizers and similarly, it was not possible to obtain higher crop yield by using organic manure alone (Bair, 1990). Sustainable crop production could be possible through the integrated use of organic manure and chemical fertilizers. Fertilization is one of the most important practices for sustained increase of agricultural production. It was estimated that the contribution of fertilization to improvement of crop production accounted for $30-50 \%$ of the total increase of the world crop yield. Proper identification and management of soil fertility problems are pre-requisite for boosting crop production and sustaining higher yields over a long period of time. A suitable combination of organic and inorganic sources of nutrients is necessary for a sustainable agriculture that will provide food with good quality and maintain a sound environment. Integrated use of organic manures and 
chemical NPK fertilizers would be quite promising not only in providing greater stability in production, but also in maintaining higher soil fertility status (Nambiar et al.,1998). The long-term research of BRRI reveals that the addition of cowdung at the rate of $5 \mathrm{t} / \mathrm{ha} / \mathrm{yr}$ improved the rice productivity as well as prevented the soil resources from degradation (Miah, 1994).

Intensive cropping is being practiced in Bangladesh. Two to three crops are in a year in most of the Level Barind Tract soil and large portion of terrace areas removing a huge quantity of nutrients from the soil annually. As a result, the level of soil fertility is diminishing gradually reflecting the need of more fertilizer application in the soil for sustaining crop production. Long-term soil fertility monitoring under a specific cropping system will be of great help in determining a better soil fertility management programme for sustained productivity at higher level. In the past, little attention was paid to soil fertility management for the cropping system as a whole rather than individual crop. To assess the fertilizer need for a cropping pattern, the first thing is to know the kind of crops that have been included in the pattern and their nutrient requirements for a target yield.

The present system of fertilizer application is mostly based on the nutrient requirement of individual crops ignoring the carry-over effect of the organic or inorganic fertilizer applied to the preceding crop. But it is known that some fertilizers have considerable residual effect on the succeeding crops, which may extend up to two/three crops. Organic or inorganic sources of nutrients applied to preceding crop can benefit the succeeding crop to a great extent (Singh et al.,1998; Hedge, 1998) and the system productivity may become sustainable through integrated use of organic and inorganic sources of nutrients (Singh and Yadav, 1992). Hence, it is important to develop a cropping system based fertilizer dose for specific agro-ecological zones.

The principal cropping patterns in Bangladesh are rice based. Rice covers nearly $80 \%$ of arable land. Modern varieties obviously require higher amount of nutrients to give higher crop yields, since the amount of nutrients taken up by a crop is closely related to the amount of biomass it produces. The farmers of this country use only about $102 \mathrm{~kg}$ nutrients/ha (70 kg N, 24 kg $\mathrm{P}_{2} \mathrm{O}_{5}, 6 \mathrm{~kg} \mathrm{~K} \mathrm{~K}_{2} \mathrm{O}, 2 \mathrm{~kg}$ $\mathrm{S}+\mathrm{Zn}$ ) annually, while the crop removal is nearly $200 \mathrm{~kg} / \mathrm{ha} / \mathrm{yr}$ (Islam et al., 1994).

The intensive cropping with modern varieties, nutrients leaching with monsoon rains and light textured soil are also favouring the emergence of micronutrient deficiency in Bangladesh soil. Consequently, Zn and B deficiency are frequently reported on some soils and crops (Jahiruddin et al., 1994). 
The development of appropriate nutrient management technologies for different cropping patterns of the country is the most important and should be the immediate goal of soil fertility research. Assessment of the nutrient requirement of different crops for desired yield levels in a cropping sequence is the first step in developing sound fertilizer management practices. Similarly, inclusion of legumes like mungbean can be used in potato based cropping systems utilizing its short duration and suitability to grow well in summer condition. A judicious integration of chemical fertilizer along with organic manure may be useful in addressing the issue of maintain soil fertility as well as crop productivity. In this context, the present study was carried out to find out a cropping system based fertilizer dose of organic and inorganic sources of nutrients and to determine the economic dose of nutrients for Potato-Mungbean-T. Aman rice cropping pattern for the Level Barind agro-ecological zone.

\section{Materials and Method}

Three experiments were carried at the MLT Site Bamonpur, Joypurhat Sadar, Joypurhat under On-Farm Research Division (OFRD), Bangladesh Agricultural Research Institute (BARI), Bogra using the cropping pattern on PotatoMungbean-T. Aman rice during 2007-08. The experiment comprised five treatments for all of the crops. It was done following discussion with local farmers, DAE personnel, and available secondary information. The fertilizer treatments used in the experiment was based on Bangladesh Agricultural Research Council Fertilizer Recommendation Guide (BARC, 2005). Before conducting the experiment, soil samples were collected from farmers' field and then sent to the SRDI laboratory, Bogra for chemical analysis. The chemical properties of the soil are presented in Table 1. The experiment was laid out in a randomized complete block design with five treatments in six dispersed replications. The unit plot size was $10 \mathrm{~m} \times 4 \mathrm{~m}$ for the whole cropping pattern. After getting the results of soil analysis, fertilizer doses were estimated with the help of soil analysis value as per treatment. The estimated fertilizer doses for Potato, Mungbean and T.aman rice were presented in the Table 2. Five different fertilizer packages were tested and the details of the treatment were as follows:

$\mathrm{T}_{1}=$ Soil test based (STB) fertilizer dose for moderate yield goal (MYG)

$\mathrm{T}_{2}=\mathrm{STB}$ fertilizer dose for high yield goal (HYG)

$\mathrm{T}_{3}=$ Integrated plant nutrient management (IPNM) approach for (HYG)

$\mathrm{T}_{4}=$ Farmers' practices (Average of 40 farmers data)

$\mathrm{T}_{5}=$ Control 
Table 1. Soil analysis values of different samples collected from MLTs, Joypurhat.

\begin{tabular}{|c|c|c|c|c|c|c|c|}
\hline \multirow{3}{*}{ Replication } & \multicolumn{7}{|c|}{ Analyzed results } \\
\hline & \multirow[b]{2}{*}{$\mathrm{pH}$} & \multirow{2}{*}{$\begin{array}{l}\text { Total } \\
\text { N (\%) }\end{array}$} & $\mathrm{P}$ & $\mathrm{K}$ & S & $\mathrm{Zn}$ & \multirow[b]{2}{*}{ OC (\%) } \\
\hline & & & PPM & $\begin{array}{c}\text { meq/100 g } \\
\text { soil }\end{array}$ & \multicolumn{2}{|c|}{ microgram/g soil } & \\
\hline 1 & 5.0 & 0.064 & 10.74 & 0.04 & 7.43 & 1.49 & 0.64 \\
\hline 2 & 5.3 & 0.089 & 13.87 & 0.10 & 7.09 & 2.99 & 0.89 \\
\hline 3 & 5.1 & 0.054 & 11.87 & 0.05 & 7.43 & 1.27 & 0.54 \\
\hline 4 & 5.2 & 0.085 & 22.55 & 0.09 & 6.08 & 0.90 & 0.85 \\
\hline 5 & 5.4 & 0.056 & 7.52 & 0.06 & 8.10 & 0.94 & 0.56 \\
\hline 6 & 5.2 & 0.069 & 13.96 & 0.10 & 6.75 & 2.40 & 0.69 \\
\hline Average & 5.2 & $0.0599 \mathrm{VL}$ & $13.41 \mathrm{~L}$ & $0.073 \mathrm{VL}$ & $7.146 \mathrm{VL}$ & $\begin{array}{c}1.655 \\
\text { OP }\end{array}$ & 0.599 \\
\hline
\end{tabular}

$\mathrm{L}=$ Low, VL=Very low, OP=Optimum

Table 2. Details of fertilizer nutrients and cowdung used for different treatments in Potato-Mungbean-T.aman rice cropping pattern during experimentation at Joypurhat MLT site during 2007-08.

\begin{tabular}{|c|c|c|c|c|c|c|c|}
\hline \multirow{2}{*}{ Treatment } & $\mathrm{N}$ & $\mathrm{P}$ & $\mathrm{K}$ & $\mathrm{S}$ & $\mathrm{Zn}$ & $\mathrm{B}$ & $\mathrm{CD}$ \\
\hline & \multicolumn{7}{|c|}{ Kg/ha } \\
\hline \multicolumn{8}{|c|}{$\underline{\text { Potato }}$} \\
\hline $\mathrm{T}_{1}(\mathrm{MYG})$ & 110 & 18 & 106 & 12 & 1.5 & 1.0 & 0 \\
\hline $\mathrm{T}_{2}(\mathrm{HYG})$ & 155 & 22 & 148 & 15 & 2.0 & 1.0 & 0 \\
\hline $\mathrm{T}_{3}(\mathrm{IPNM})$ & 132 & 15 & 123 & 8 & 2.0 & 1.0 & 5000 \\
\hline $\mathrm{T}_{4}(\mathrm{FP})$ & 140 & 15 & 100 & 15 & 0 & 0 & 4000 \\
\hline $\mathrm{T}_{5}$ Control) & 0 & 0 & 0 & 0 & 0 & 0 & 0 \\
\hline \multicolumn{8}{|c|}{ Mungbean } \\
\hline $\mathrm{T}_{1}(\mathrm{MYG})$ & 17 & 20 & 33 & 15 & 0 & 0 & 0 \\
\hline $\mathrm{T}_{2}$ (HYG) & 20 & 22 & 40 & 18 & 0 & 0 & 0 \\
\hline $\mathrm{T}_{3}(\mathrm{IPNM})$ & \multicolumn{7}{|c|}{ Same as $\mathrm{T}_{2}$} \\
\hline $\mathrm{T}_{4}(\mathrm{FP})$ & 22 & 18 & 30 & 15 & 0 & 0 & 0 \\
\hline $\mathrm{T}_{5}$ Control) & 0 & 0 & 0 & 0 & 0 & 0 & 0 \\
\hline \multicolumn{8}{|c|}{ T. Aman rice } \\
\hline $\mathrm{T}_{1}(\mathrm{MYG})$ & 72 & 9 & 43 & 9 & 0 & 0 & 0 \\
\hline $\mathrm{T}_{2}(\mathrm{HYG})$ & 103 & 11 & 60 & 12 & 0 & 0 & 0 \\
\hline $\mathrm{T}_{3}(\mathrm{IPNM})$ & \multicolumn{7}{|c|}{ Same as $\mathrm{T}_{2}$} \\
\hline $\mathrm{T}_{4}(\mathrm{FP})$ & 90 & 15 & 30 & 15 & 0 & 0 & 0 \\
\hline $\mathrm{T}_{5}$ Control) & 0 & 0 & 0 & 0 & 0 & 0 & 0 \\
\hline
\end{tabular}


Potato tuber was sown on 30 November to 5 December 2007. Sowing was made at the rate of $2000 \mathrm{~kg} / \mathrm{ha}$. A distance of $60 \mathrm{~cm}$ from row to row and $25 \mathrm{~cm}$ from plant to plant was maintained. One seedling was used in each hill. The full dose of cowdung, triple super phosphate (TSP), muriate of potash (MoP), gypsum, zincsulphate, boric acid, and one- half of urea were applied in potato at the time of final land preparation. Remaining urea was applied at the side row and covered with soil about 30-35 days after planting (DAP) at the time of earthing up followed by irrigation. Different intercultural operations were done to ensure normal growth of the crops, earthing up was done during 30-35 DAP, irrigation was provided after 12-15, 30-35, and 45-50 DAP, fungicide was sprayed three times during the whole growth period i.e., Indofil was sprayed at 25 and 35 DAP, Secure was sprayed at 45 DAP. Crop was harvested plot-wise at maturity. The date of harvest was 25 to 29 February 2008. The second test crop in the experiment in the cropping pattern used was mungbean. The mungbean variety used was BARI Mung-6.

Seeds were sown on 6-8 March 2008. Sowing was made at the rate of 45 $\mathrm{kg} / \mathrm{ha}$. Seeds were sown continuously in lines and were covered by soil with the help of hand. The line to line distance was $30 \mathrm{~cm}$. All fertilizers should be broadcast and incorporated at the time of final land preparation. . The crop was harvested plot-wise at maturity. Pods were picked up from the plant at a time. Biomass of mungbean was ploughed down after the harvest. The date of harvest was 15 to 18 May, 2008 from different replications.

The third test crop used in the experiment was BR11. For raising of the seedling, a previously prepared well puddle land selected for the seedling nursery. The sprouted seeds were broadcast on the prepared seedling nursery. Seeds were sown uniformly as possible and covered with a thin layer of fine earth. Fourty (40) days old seedling were transplanted in the experimental plots on 25-27 July 2008. A distance of $20 \mathrm{~cm}$ from row to row and $15 \mathrm{~cm}$ from plant to plant was maintained. Three seedlings were used in each hill. The full amount of triple superphosphate (TSP), muriate of potash (MoP) and gypsum were applied as broadcast and incorporated with soil during final land preparation. Urea was applied in three equal splits, 1/3 urea at 15 days after transplanting, 1/3 urea at rapid tillering stage as broadcast with incorporation to soil followed by weeding and rest $1 / 3$ urea as broadcast at 5-7 days before panicle initiation stage. The crop was harvested at full maturity which required about $31 / 2$ Months from the date of transplanting. The crop was harvested plot-wise on 6-10 November 2008. Data on yield and yield contributing characters of potato, mungbean, and T. aman rice were recorded and analyzed statistically. Statistical analysis for using the "analysis of variance" and mean difference were adjudged by Duncan's Multiple Range Test (DMRT). 


\section{Results and Discussion}

Tuber yield of potato responded significantly to mineral fertilizer as well as combined treatments of mineral fertilizer and cowdung (Table 3). The tuber yield ranged form 2.46 to $25.01 \mathrm{t} / \mathrm{ha}$ as observed in $\mathrm{T}_{5}$ (control) and $\mathrm{T}_{3}$ (IPNM) treatments, respectively. The highest tuber yield (25.01 t/ha), which was observed in $\mathrm{T}_{3}$ treatment and it was significantly higher than $\mathrm{T}_{1}, \mathrm{~T}_{4}, \mathrm{~T}_{5}$ treatments, but statistically identical with $\mathrm{T}_{2}$ (HYG) treatment. The lowest tuber yield (2.46 $\mathrm{t} / \mathrm{ha}$ ) was recorded in control $\left(\mathrm{T}_{5}\right)$ treatment. The yield increase of $T_{3}$ treatment was obtained 22.55 t/ha (917\% increase) over control. Annual Report 2006-07, BARI, reported that the two years' results, the highest tuber yield was obtained from IPNM based fertilizer dose treatment in 2004-05 and the yield was statistically similar to STB fertilizer dose for HYG treatment in 2005-06.

Table 3. Effects of different treatments on the tuber yields of potato (cv. Dimant) under Potato Mugbean -T. Aman rice cropping pattern of Joyparhat MLT site during 2007-2008.

\begin{tabular}{l|c|c|c}
\hline \multirow{2}{*}{ Treatment } & \multicolumn{3}{c}{ Tuber yield } \\
\cline { 2 - 4 } & Yield (t/ha) & $\begin{array}{c}\text { Increase over } \\
\text { control (t/ha) }\end{array}$ & $\begin{array}{c}\text { Increase over } \\
\text { control (\%) }\end{array}$ \\
\hline $\mathrm{T}_{1}=\mathrm{N}_{110} \mathrm{P}_{18} \mathrm{~K}_{106} \mathrm{~S}_{12} \mathrm{Zn}_{1.5} \mathrm{~B}_{1}$ & $15.89 \mathrm{c}$ & 13.43 & 546 \\
$\mathrm{~T}_{2}=\mathrm{N}_{155} \mathrm{P}_{22} \mathrm{~K}_{148} \mathrm{~S}_{15} \mathrm{Zn}_{2} \mathrm{~B}_{1}$ & $24.84 \mathrm{a}$ & 22.38 & 910 \\
$* \mathrm{~T}_{3}=\mathrm{N}_{132} \mathrm{P}_{14} \mathrm{~K}_{123} \mathrm{~S}_{8} \mathrm{Zn}_{2} \mathrm{~B}_{1} \mathrm{CD}_{5000} \mathrm{~kg}$ & $25.01 \mathrm{a}$ & 22.55 & 917 \\
$\mathrm{~T}_{4}=\mathrm{N}_{140} \mathrm{P}_{15} \mathrm{~K}_{100} \mathrm{~S}_{12} \mathrm{CD}_{4000} \mathrm{~kg}$ & $19.85 \mathrm{~b}$ & 17.39 & 707 \\
$\mathrm{~T}_{5}=\mathrm{Control}_{\text {Level of significance }}$ & $2.46 \mathrm{~d}$ & - & - \\
$\mathrm{CV}$ (\%) & $* *$ & - & - \\
\hline
\end{tabular}

Means followed by the same letter in a column are not statistically significant at $1 \%$ level in DMRT.

** Significant at $1 \%$ level

* Cowdung was applied in the first crop (Potato) only and its residual effects were assessed in the following mungbean and T. Aman rice crops in the cropping sequence.

There was a significant and positive effect of different treatments of fertilizers and manure on seed yield of mungbean (Table 4). It appeared that the seed yields increased with the application of increasing levels of NPKS. The seed yield varied from 305 to $1384 \mathrm{~kg} / \mathrm{ha}$ in the experiment. The highest seed yield (1384 kg/ha) was recorded in treatment $\mathrm{T}_{3}$ (NPKS for HYG + residual CD), which was statistically different with all other treatments. The lowest seed yield 
(305 kg/ha) was obtained in control $\left(T_{5}\right)$ treatment, which was significantly different with all other treatments. The yield increase of $T_{3}$ (NPKS for HYG + residual CD) was obtained $1079 \mathrm{~kg} / \mathrm{ha}$ (353\% increase) over control $\left(\mathrm{T}_{5}\right)$ treatment. It also appeared that the treatment $\mathrm{T}_{3}$ demonstrated significant residual effect of cowdung applied to the previous crop (Potato). The results indicated that NPKS for HYG treatments which contained higher amount of NPKS gave higher yield compared to NPKS for MYG and NPKS for FP treatments. BARI (2008) reported that the similar experiment was carried out during the rabi season of 2007-08 at Atgoria, Pabna to find out a cropping pattern based fertilizer recommendation and determine the economic dose of fertilizer for PotatoMungbean-T. Aman rice cropping pattern. The highest tuber yield was obtained from integrated plant nutrient management (IPNM) and the lowest from control treatment.

Table 4. Effects of different treatments on the seed yield of mungbean (BARI mung6) under Potato-Mungbean-T. Aman rice cropping pattern at Joypurhat MLT site during 2007-08.

\begin{tabular}{l|l|l|l}
\hline \multirow{2}{*}{ Treatment } & \multicolumn{3}{c}{ Seed yield } \\
\cline { 2 - 4 } & \multicolumn{1}{c}{ Yield (kg/ha) } & $\begin{array}{c}\text { Yield increase over } \\
\text { control (kg/ha) }\end{array}$ & $\begin{array}{c}\text { Yield increase over } \\
\text { control (\%) }\end{array}$ \\
\hline $\mathrm{T}_{1}=\mathrm{N}_{17} \mathrm{P}_{20} \mathrm{~K}_{33} \mathrm{~S}_{15}$ & $976 \mathrm{~d}$ & 671 & 220 \\
$\mathrm{~T}_{2}=\mathrm{N}_{20} \mathrm{P}_{22} \mathrm{~K}_{40} \mathrm{~S}_{18}$ & $1281 \mathrm{~b}$ & 976 & 320 \\
$\mathrm{~T}_{3}=\mathrm{Same}_{2} \mathrm{~T}_{2}$ & $1384 \mathrm{a}$ & 1079 & 353 \\
$\mathrm{~T}_{4}=\mathrm{N}_{22} \mathrm{P}_{18} \mathrm{~K}_{30} \mathrm{~S}_{15}$ & $1067 \mathrm{c}$ & 762 & 250 \\
$\mathrm{~T}_{5}=\mathrm{N}_{0} \mathrm{P}_{0} \mathrm{~K}_{0} \mathrm{~S}_{0}$ & $305 \mathrm{e}$ & - & - \\
\hline Level of significance & $* *$ & - & - \\
CV (\%) & 4.87 & - & - \\
\hline
\end{tabular}

Means followed by the same letter in a column are not statistically significant at $1 \%$ level in DMRT.

** Significant at $1 \%$ level

The grain yield was significantly affected due to the different treatments (Table 5). The grain yield varied from 1.50 to $5.68 \mathrm{t} / \mathrm{ha}$ (Table 5). The highest grain yield (5.68 t/ha) was recorded in $\mathrm{T}_{3}$ (NPKS for HYG + residual cowdung) which was significantly different with all other treatments. The lowest grain yield $\left(1.50 \mathrm{t} / \mathrm{ha}\right.$ ) was observed in $\mathrm{T}_{5}$ (control) treatment. The grain yield of $5.37 \mathrm{t} / \mathrm{ha}$ produced in $\mathrm{T}_{4}(\mathrm{FP})$ treatment which was significantly higher compared to $\mathrm{T}_{1}$ (MYG) treatment. The results indicated that NPKS for HYG with residual cowdung $\left(T_{3}\right)$ treatment gave higher grain yield compared to the all other treatments. In case of straw yield, significantly the highest yield (5.82 t/ha) was also obtained from $T_{3}$ (IPNM) treatment, but it was statistically identical with $T_{2}$ 
treatment and significantly different with all other treatments. Sengar et al. (2000) stated that the application of chemical fertilizer in combination with manure sustained/improved the fertility status of the soil. Hasan et al. (2004) reported that the combined effect of poultry manure and inorganic fertilizer combinations (NPKS) had significant effect on most of the crop characters. Similar results observed that 50:40:30 kg NPK per ha + 3t CD and urea mixture produced significantly higher grain yield compared with the application of inorganic fertilizer alone reported by Jha et al. (2004). Similar results also observed by BARI (2008). Thus the results indicated that NPKS for HYG with residual cowdung gave the highest grain yield from integrated plant nutrient management and the lowest from control treatment.

Table 5. Effects of different treatments on the grain and the straw yields of T. Aman rice (cv, BR11) under Potato-Mungbean-T. Aman rice cropping pattern at Joypurhat MLT site during 2007-08.

\begin{tabular}{l|l|c|c|c|c|c}
\hline & \multicolumn{3}{c|}{ Grain } & \multicolumn{3}{c}{ Straw } \\
\cline { 2 - 8 } Treatment & $\begin{array}{c}\text { Yield } \\
(\mathrm{t} / \mathrm{ha})\end{array}$ & $\begin{array}{c}\text { Increase } \\
\text { over } \\
\text { control } \\
(\mathrm{t} / \mathrm{ha})\end{array}$ & $\begin{array}{c}\text { Increase } \\
\text { over } \\
\text { control } \\
(\%)\end{array}$ & $\begin{array}{c}\text { Yield } \\
\text { (t/ha) }\end{array}$ & $\begin{array}{c}\text { Increase } \\
\text { over } \\
\text { control } \\
(\mathrm{t} / \mathrm{ha})\end{array}$ & $\begin{array}{c}\text { Increase } \\
\text { over } \\
\text { control } \\
(\%)\end{array}$ \\
\hline $\mathrm{T}_{1}=\mathrm{N}_{72} \mathrm{P}_{9} \mathrm{~K}_{43} \mathrm{~S}_{9}$ & $4.17 \mathrm{~d}$ & 2.67 & 178 & $4.31 \mathrm{c}$ & 2.71 & 169 \\
$\mathrm{~T}_{2}=\mathrm{N}_{103} \mathrm{P}_{11} \mathrm{~K}_{60} \mathrm{~S} 12$ & $5.50 \mathrm{~b}$ & 4.00 & 267 & $5.60 \mathrm{a}$ & 4.00 & 250 \\
$\mathrm{~T}_{3}=\mathrm{Same} \mathrm{as}_{2}$ & $5.68 \mathrm{a}$ & 4.18 & 279 & $5.82 \mathrm{a}$ & 4.22 & 264 \\
$\mathrm{~T}_{4}=\mathrm{N}_{90} \mathrm{P}_{15} \mathrm{~K}_{30} \mathrm{~S} 15$ & $5.37 \mathrm{c}$ & 2.87 & 191 & $4.47 \mathrm{~b}$ & 2.97 & 186 \\
$\mathrm{~T}_{5}=\mathrm{N}_{0} \mathrm{P}_{0} \mathrm{~K}_{0} \mathrm{~S}_{0}$ & $1.50 \mathrm{e}$ & - & - & $1.60 \mathrm{~d}$ & - & - \\
\hline Level of significance & $* *$ & - & - & $* *$ & - & - \\
$\mathrm{CV}$ (\%) & 5.41 & - & - & 9.13 & - & - \\
\hline
\end{tabular}

Means followed by the same letter in a column are not statistically significant at $1 \%$ level of DMRT.

** Significant at $1 \%$ level.

\section{Agro-economic performance}

Cost and return analysis of different treatments on Potato -Mungbean -T. Aman rice cropping patterns during 2007-08 have been presented in Table 6. In performing this analysis, variable costs have been only considered and fixed costs have been ignored. Variable costs included variable money cost and variable opportunity costs. Variable money cost was the purchasing price of fertilizer and cow dung. Variable opportunity cost included the amount of money paid for carrying and broadcasting the fertilizers and cow dung. Total gross return was calculated as the total market value of tuber, seeds of mungbean, grain and straw yield of T. Aman rice. Gross margin was calculated by subtracting the variable cost from the total gross return. Marginal benefit cost ratio (MBCR) was 
calculated by subtracting the total gross return of control treatment from the total gross return of other treatments (From $\mathrm{T}_{1}$ to $\mathrm{T}_{4}$ ) dividing by the variable cost. The data are shown in Table 6.

The results of cost and return analysis from the crops (Potato, Munngbean, T. Aman rice) are taken together in the cropping sequence Table 6 demonstrated that the highest gross margin (Tk. 3,43,360/ha) and marginal benefit cost ratio (8.64) was obtained from $T_{3}$ (IPNM) treatment which was followed by Tk.3,32,297/ha obtained from $\mathrm{T}_{2}$ (HYG) treatment. The treatment $\mathrm{T}_{1}(\mathrm{MYG})$ produced the lowest gross margin (Tk. 2,31,842/ha) and MBCR (7.72) over control treatment and it was followed by Tk.2,67,128/ha and MBCR 7.74 obtained from $\mathrm{T}_{4}$ (FP) treatment.

However, the marginal benefit cost ratio (MBCR) of the treatments was found to follow the sequence $T_{3}>T_{2}>T_{4}>T_{1}$. Regarding cost and return analysis, higher gross margin and MBCR was obtained from $\mathrm{T}_{3}$ (IPNM) treatment. To sustain and increase crop productivity, farmers should use balanced inorganic fertilizer and preferably integrated fertilizer management with organic and inorganic fertilizers which could help maintain and improve soil health. Farmers should apply organic manure at least once in a year along with inorganic fertilizers for maintaining long-term soil fertility and sustainable higher yield.

Table 6. Agro-economic performance of different treatments in Potato-MungbeanT. Aman rice cropping pattern at Joypurhat MLT site during 2007-08.

\begin{tabular}{|c|c|c|c|c|c|c|c|}
\hline \multirow[b]{2}{*}{ Treatment } & \multicolumn{3}{|c|}{ Gross return (Tk./ha) } & \multirow{2}{*}{\begin{tabular}{|c|} 
Total \\
gross \\
return \\
(Tk./ha)
\end{tabular}} & \multirow{2}{*}{$\begin{array}{c}* \\
\text { Variable } \\
\text { cost } \\
\text { (Tk./ha) }\end{array}$} & \multirow{2}{*}{$\begin{array}{c}\text { Gross } \\
\text { margin } \\
\text { (Tk./ha) }\end{array}$} & \multirow[b]{2}{*}{ MBCR } \\
\hline & Potato & Mungbean & T. Aman & & & & \\
\hline MYG $\left(\mathrm{T}_{1}\right)$ & 127120 & 58560 & 71170 & 256850 & 25008 & 231842 & 7.72 \\
\hline $\operatorname{HYG}\left(\mathrm{T}_{2}\right)$ & 198720 & 76860 & 93700 & 369280 & 36983 & 332297 & 8.26 \\
\hline IPNM $\left(\mathrm{T}_{3}\right)$ & 200080 & 83040 & 96840 & 379960 & 36600 & 343360 & 8.64 \\
\hline $\mathrm{FP}\left(\mathrm{T}_{4}\right)$ & 158800 & 64020 & 74490 & 297310 & 30180 & 267128 & 7.74 \\
\hline Control $\left(\mathrm{T}_{5}\right)$ & 19680 & 18300 & 25700 & 63680 & 0 & 63680 & - \\
\hline
\end{tabular}

* Fertilizer cost only Input cost (Tk./kg)

$\begin{array}{ll}\text { 1. Urea } & =\text { Tk. } 6.00 \\ \text { 2. TSP } & =T k \cdot 40.00 \\ \text { 3. MoP } & =\text { Tk. } 40.00 \\ \text { 4. Gypsum } & =\text { Tk. } 6.00 \\ \text { 5. Zinc sulphate } & =\text { Tk. } 120 \\ \text { 6. Boric acid } & =\text { Tk. } 60 \\ \text { 7. Cowdung } & =\text { Tk. } 0.75\end{array}$

Products (Tk./kg)

$\begin{array}{ll}\text { 1. } \text { Potato } & =\text { Tk. } 8.00 \\ \text { 2. } \text { Mungbean } & =\text { Tk. } 60.00 \\ \text { 3. T. Aman } & =\text { Tk. } 15.00 \\ \text { 4. } \text { Rice straw } & =\text { Tk. } 2.0\end{array}$




\section{Conclusion}

From the above study, it may be concluded that the integrated plant nutrient treatment $\left(\mathrm{T}_{3}\right)$ was found agronomically viable and economically profitable under Potato -Mungbean -T. Aman rice cropping pattern at Joypurhat and similar soils of Level Barind agro-ecological zone. So, considering crop productivity, economic return and soil fertility, integrated plant nutrient management for high yield goal (HYG) with 5 t/ha cowdung could be recommended for the PotatoMungbean-T. Aman rice cropping pattern at Joypurhat and similar soils of Level Barind agro-ecological zone for sustainable higher yield.

\section{References}

Bair, W.1990. Characterization of the environment for sustainable agriculture in SemiArid Tropics. In: Proceedings Sustainable Agriculture. Issues, Perspectives and Prospects in Semi-Arid Tropics (Ed. Singh, R.P.) Hydarabad, India. Indian Soc. Agron. 1 : 90-128.

BARC. 2005. Fertilizer Recommendation Guide-2005, BARC, Soils Pub. No.45, Bangladesh Agril. Res. Council, Farmgate, Dhaka-1215.

BARI. 2007. Annual Research Report, 2006-2007. On-Farm Res. Div. Bangladesh Agril. Res. Inst., Joydebpur, Gazipur, pp. 10, 39, 42, 44, 46.

BARI. 2008. Annual Research Report, 2007-2008. On-Farm Res. Div. Bangladesh Agril. Res. Inst., Joydebpur, Gazipur, pp.56-57, 137.

Bhuiyan, N. I.; A. L. Shaha and G. M. Panaullah. 1991. Effect of NPK fertilizer on the grain yield of transplanted rice and soil fertility long term study. Bangladesh J. Soil. Sci. 22 (1\&2):41-50.

Hasan, M.K,. M.A.R. Sarkar and A.K. Hassan. 2004. Effect of poultry manure based integrated fertilizer management on growth and yield of aromatic rice. Bangladesh $\mathrm{J}$. Seed Sci. \& Tech. 8(1\&2): 97-103.

Islam, M. S., M. S. Amin and , M.N. Anwar.1994. Integrated soil fertility management in Bangladesh. Paper presented at the Workshop on Integrated Nutrient Management for Sustainable Agriculture, held at SRDI, Dhaka, Bangladesh, June 26-28, 1994.

Jahiruddin, M., M.N.Islam, M.A. Hashem and A.C. Islam. 1994. Influence of sulphur, zinc and boron on yield and nutrient uptake of BR 2 rice. Progress. Agric. 5 (1) 61-67.

Jha, S. K., R.S. Tripathi, Sanjeev and Malaiya. 2004. Influence of integrated nutrient management practices on growth and yield of scented rice (Oryza sativa L.). Ann. Agril. Res. 25 (1): 159-161.

Karim, Z., M. M.U. Miah and S. Razia. 1994. Fertilizer in the national economy and sustainable environmental development. Asia Pacific J. Environ. Dev. 2: 48-67.

Miah, M. M. U. 1994. Prospects and problems of organic farming in Bangladesh. Paper presented at the Workshop on Integrated Nutrient Management for Sustainable Agriculture held at SRDI, Dhaka, June-26-28, 1994. 
Mollah, M. R. A., K. M. Khalequzzaman, M. M. Hossain and , S. M. L. Rahman.2008. Cropping pattern based fertilizer recommendation for Mustard-Boro-T. Aaman rice cropping pattern under AEZ-25 at Nandigram, Bogra. J. Soil Nature. 2 (2): 31-34.

Nambiar, K. K. M., J. Sehgal, W. E. Blum and K. S. Gajbhiye. 1998. Integrated use of organic manures and chemical fertilizers in red soils for sustainable agriculture. Red and Lateritic Soils. Managing red and lateritic soils for sustainable agriculture, Vol. 1. pp. 367-376.

Pradhan, S. B. 1992. "Status of fertilizer use in developing countries of Asia and the Pacific region”, Proc. regional FADINAP seminar, Chiang Mai,Thailand. pp. 37-47.

Sengar, S. S., L. J.Wadem, S. S. Baghel, R. K. Singh and G. Singh. 2000. Effect of nutrient management of rice (Oryza sativa L.) in rainfed low land of Southeast Madhya Pradesh. Indian J. Agron. 45 (2): 315-322.

Singh, G. B. and D. V.Yadav. 1992. Integrated nutrient management in sugarcane and sugarcane based cropping system. Fert. News. 37(4):15-20. 